Domaines, territoires et frontières en anglais de spécialité

\title{
To quote or not to quote: "Literature in law" in European court decisions and legal English teaching
}

\section{Géraldine Gadbin-George}

\section{CpenEdition}

\section{Journals}

Electronic version

URL: http://journals.openedition.org/asp/3842

DOI: $10.4000 /$ asp.3842

ISSN: 2108-6354

\section{Publisher}

Groupe d'étude et de recherche en anglais de spécialité

Printed version

Date of publication: 1 November 2013

Number of pages: 75-93

ISSN: 1246-8185

\section{Electronic reference}

Géraldine Gadbin-George, « To quote or not to quote: "Literature in law" in European court decisions and legal English teaching », ASp [Online], 64 | 2013, Online since 01 November 2014, connection on 02 November 2020. URL : http://journals.openedition.org/asp/3842 ; DOI : https://doi.org/10.4000/ asp.3842

This text was automatically generated on 2 November 2020.

Tous droits réservés 


\title{
To quote or not to quote: "Literature in law" in European court decisions and legal English teaching
}

\author{
Géraldine Gadbin-George
}

1 American director and writer Orson Welles once wrote:

Shakespeare said everything. Brain to belly; every mood and minute of a man's season. [...] He speaks to everyone and we all claim him but it's wise to remember [...] that he doesn't properly belong to us but to another world [...]. Shakespeare speaks everybody's language, but with an Elizabethan accent. (1939: 22)

2 Law, justice and the legal profession often play a part in Shakespeare's works. A lot of his plays "take law for a theme, and feature a trial ([...] The Merchant of Venice, [...]), conflicting jurisprudential theories ([...] King Lear), the relation of law to vengeance ([...] Hamlet [...]" (Posner 2009: xi). Shakespeare may not have liked lawyers (his character Dick the Butcher advised to "kill all the lawyers")1 but he knew about justice. He is even rumoured to have trained as a lawyer (Senter 1903). The Law Society, which is the professional body of solicitors of England and Wales, pondered over that question:

Was Shakespeare a lawyer? [...] a bright literate young man seeking his fortune in 16th century London would have been quite likely to obtain some sort of work in the courts, perhaps as an attorney's apprentice. One can imagine that after a time Shakespeare was more than happy to exchange the exacting arena of the court for the carefree life of the theatre. (The bard and the Bench 1987)

According to Shakespeare specialist and English barrister William Lowes Rushton, whether William Shakespeare was or was not a member of the legal profession [...], he had acquired [...] the accumulated wisdom of ages, the stronghold of freedom, of civil [...] liberty, the wisest, the noblest, the most fair and equitable system of jurisprudence [...] that the human race in any age or any clime has ever yet beheld. (1918: 50)

After being quoted by the common law judiciary and legal professions, Shakespeare has now found favour with judges from the European Court of Justice and the European 
Court of Human Rights. Shakespeare's works are thus at the crossroads of law and literature, common law and civil law, and the legal cultures of the different countries which belong to the European Union. Shakespeare is not the only writer whose works are used in British, American or European court decisions. He is one of many, maybe less universal or less known, whom judges like to mention.

From the "Law and Literature" movement which initially gave birth to two submovements, "Law in Literature" and "Literature as Law", a third sub-movement has emerged, which could be called "Literature in Law". The use of literary quotations or references in court decisions or legal pleadings has already led a growing number of Anglophone law instructors to integrate the study of literature into the law curriculum. With the emergence of "Literature in Law" in the European courts, literature in general -and Shakespeare in particular- could become an element of legal English teaching in law schools across Europe.

5 A number of European court decisions are considered below. The aim is to determine the place occupied by literature (and more specifically Shakespeare) in the European judicial process, and to identify the difficulties which the development of a "Literature in Law" movement at European court level entails for those teaching legal English to aspiring lawyers.

\section{European courts: at a crossroads between various cultures}

6 The European courts are a melting pot of different national and legal cultures. However, they must comply with a unified set of rules. There are two European courts, the European Court of Justice (ECJ) and the European Court of Human Rights (ECHR). Both courts are young: the ECJ was set up in 1952, the ECHR in 1959. The jurisdictional scope of the ECJ was extended with the Maastricht Treaty of 1992 and the Lisbon Treaty of 2007.

7 The role of the ECJ is to interpret European Union law to ensure its uniform application throughout Europe. Each country is represented by one judge only. ${ }^{2}$ The official language of the judgement is that of the dispute, although all decisions are translated in all European languages, including English. The role of the ECHR is to ensure that European country members comply with the European Convention of Human Rights. The official languages of the ECHR are French and English, even though all European nationalities are represented amongst the judges. European court decisions are binding on all national courts of European Union members.

8 All European court judges are initially trained in their native countries. For instance, British European court judges will be conversant with the common law in which they initially practised. Conversely, French European judges will have previously practised French law, which is a civil law system. This is important, in that all European court judges will fit into a national mould before moving on to the ECJ or the ECHR and adopting the European mould.

9 Apart from procedural differences (which are outside the scope of this study), the main difference between the common law and civil law systems resides in the way judgements are drafted. According to William Tetley, common law judgements "extensively expose the facts [...], and decide (if not create) the specific legal rule 
relevant to the present facts. Civil law decisions first identify the legal principles that might be relevant, then verify if the facts support their application [...]" (1999: 3). American Supreme Court Justice Ruth Ginsburg explains that in civil law countries, no dissenting opinions are expressed in the court judgement:

In the civil-law tradition [...] courts [...] issue a collective judgment, cast in stylized, impersonal language. [...] Disagreement [...] is not disclosed. The British commonlaw tradition lies at the opposite pole. [...] [T] he judges hearing the case composed their own individual opinions which, taken together, revealed the court's disposition. (2010:2)

For George Letsas, "Separate opinions in the common law allow individual judges publicly to develop, much like an academic would, their own legal philosophy [...]. In the tradition of civil law by contrast, judges remain largely unknown to the public and to the legal profession [...]" (2011: 1-2). All these factors explain why literature has no place in the drafting of civil law judgments.

The ECJ's and ECHR's respective judgements are a hybrid combination of the common law and civil law systems. Most European continental countries have a civil law system, which has an influence over the contents of European legislation. However, the ECJ's and ECHR's respective procedures resemble the common law system. Judges are thus encouraged to detail their reasoning in their opinions.

The legal discrepancies between common law and civil law systems lead to cultural differences in the judges' approach to literature. These differences originate in the training they receive at law school.

In her 1989 survey, Elizabeth Villiers Gemmette stressed the role played by literature in legal training in common law countries. Referring to United States law schools, she explained that 38 out of 135 colleges offered a law and literature course of some sort. Harvard offered a specific "Dickens and the law" course (1989: 269). Giacomo Oberto (2003) conducted a comparative study of the programmes taught to aspiring judges throughout Europe. A number of English law schools (such as Kent Law School, according to its website) now teach law and literature courses.

Unlike common law countries, civil law countries have not yet integrated literature into their legal training. At the Paris law school which trains future avocats, the study of literature is not available (Ordre des Avocats de Paris website) nor is it at the École Nationale de la Magistrature which trains future French judges (see its website). French avocats or judges who aim to deal with European law should become familiar with the hybrid legal system of the European courts. This is why the aim of this study was to investigate the part played by literature, and more precisely Shakespeare, in ECJ and ECHR decisions, and its possible effects on legal English instruction for law students in Europe.

\section{Shakespeare in European court decisions}

15 Literary quotations of or references to authors like Montesquieu, ${ }^{3}$ Balzac, ${ }^{4} \mathrm{Kafka}^{5}$ or Faulkner ${ }^{6}$ can be found in European court decisions. They could have been chosen for this study. However Shakespeare seemed a better choice for the following reasons: first, lawyers (including those who become judges) have a particular fondness for Shakespeare.7 For Robert Peterson, "the beauty, flare, and uniqueness of language accounts for much of Shakespeare's popularity in briefs and opinions" (1999: 793). 
Then, Shakespeare had an interest for judicial matters. Moreover the mystery which surrounds Shakespeare makes his plays more appealing to lawyers and lay readers. ${ }^{8}$ And finally Shakespeare is of interest to most, if not all those who teach English, including legal English specialists.

One of the aims of this study was to determine when, how and for what reasons literature -and more specifically Shakespeare- is used by European court judges. Literature can be a way to make court decisions easier to understand and the judicial process more user-friendly. Conversely, an inappropriate or irrelevant use of literature can make it more difficult to understand a court decision. It may even mislead the litigant.

\subsection{Methodology}

\subsubsection{Identifying court decisions}

17 This study focuses on European court decisions written in English. Unless stated otherwise, the decisions referred to were found on the British and Irish Legal Information Institute website ("BAILII"). The nationality of the European court judges using Shakespeare's works in their opinions is mentioned whenever relevant.

Two different methods were employed to find references to or quotations from Shakespeare's works. First the word "Shakespeare" was entered in the "Europe" database of BAILII, which allowed to identify ten decisions. Two of these decisions had no link with Shakespeare's plays. One was a European trademark dispute involving the Royal Shakespeare Theatre. ${ }^{9}$ The other one included a reference to an address on Shakespeare Street. ${ }^{10}$ The other eight entries were relevant and are set out in Appendix 1 . Then the names of all the plays usually attributed to Shakespeare were entered into the BAILII database. Nine results appeared when looking up six famous plays by Shakespeare: The Merchant of Venice, Romeo and Juliet, Julius Caesar, Macbeth, Hamlet and Othello. The results are set out in Appendix 2, and correlate with Appendix 1.

of course, these results do not offer a comprehensive sample of the way Shakespeare is used in legal texts. Speaking of references to or quotations of Shakespeare in the United States Supreme Court decisions, Professor Robert H. Skilton noted that "no attempt was made to search for references to Shakespeare's works absent his name because of the obvious magnitude of such a task" (1991: 8). A similar admission is made here.

\subsubsection{Deconstructing court decisions as an analysis tool}

When confronted with a court case study, students need to "deconstruct" the court decision by considering the factual issues and subsequently the legal points. French philosopher Jacques Derrida wrote: “Deconstruction [...] means not 'destroying' but 'undoing', while analysing the different layers of a structure to know how it has been built [...]. Deconstruction [...] emphasized the history of the construction [...]" (1986: 2). Law lecturers need to teach their students how to "break down" court decisions into factual and legal issues. Those teaching legal English have a double and simultaneous mission to fulfil when the court decisions they discuss with their students include literary references or quotations. While teaching legal English vocabulary remains a key objective, they must introduce the general use of such references, and show 
students how a literary reference or quotation fits in with factual explanations or legal reasoning.

In the next section, observations from the analysis of some European court decisions referring to or quoting Shakespeare are reported. The purpose is to try to identify the reasons why literary quotations or references are made.

\subsection{Analysis of European court decisions}

22 As the legal facts and language of court decisions may be complex, in the discussion of each decision, the reader is first provided with the general finding regarding the effectiveness of the use of literary references. This is then followed by a brief statement about the case and the legal issues involved. The actual literary reference or quotation is then presented, followed by a more specific observation of the effectiveness of the literary reference or quotation.

\subsubsection{Attempt to clarify the facts of a case}

23 Two ECJ court decisions are reported here. Mucksch v. Franz Mucksch deals with the interpretation of the Seveso II Directive. The German State referred the case to the ECJ. The litigation revolved around the distance required between areas of public use and establishments where dangerous substances were present. In a footnote to paragraph 46 of her opinion and whilst considering the concept of appropriate distance, Advocate General Sharpston held: "It is common ground that Merck's establishment was originally situated at a greater distance from the city, parts of which have crept towards it -reminding the agent for the German Government, as he stated at the hearing, of Birnam Wood coming to Dunsinane (Macbeth, Act 5)".

Mrs Sharpston is a qualified English barrister and an academic. She turned to law after going through her "classics" (according to the Durham University website). The German authorities' representative referred to Macbeth. When he compared the creeping of the city towards Merck's establishment (where the hazardous substances used may present a substantial danger for health and safety) to the coming of Birnam Wood to Dunsinane, he aimed to strike a chord with the court. Macbeth had not considered that a wood (Malcolm's army camouflaged as trees) could move and attack his castle. Similarly, Merck had not considered that the city would develop close enough to the factory to cause health and safety problems.

Judge Sharpston obviously found the German government's reference to Macbeth to be a persuasive factual argument as she used it in her opinion. The Shakespearean reference is relevant but a good understanding and knowledge of Shakespeare's work is necessary to see the appropriateness of the point raised here.

In Blanco Perez \& Chao Gomez (Freedom of establishment), two qualified pharmacists disputed before the ECJ the compliance of a Spanish decree with a European Treaty on the right to freedom of establishment. The two pharmacists had been denied the right to open a pharmacy under that decree which limited the number of pharmacies in the area. In the first paragraph of his opinion, Advocate General Poiares Maduro held:

The concern that pharmacists in need of money may compromise their professional obligations is not new. It has been a matter of concern at least since Shakespeare's Romeo convinced a 'caitiff wretch' of an apothecary to sell him poison with the lines: 
'... famine is in thy cheeks,

Need and oppression starveth in thine eyes,

Contempt and beggary hangs upon thy back;

The world is not thy friend nor the world's law;

The world affords no law to make thee rich;

Then be not poor, but break it, and take this. (Romeo and Juliet, Act 5, Scene 1)

The judge transposed to modern days the Shakespearean era when apothecaries were numerous and had difficulties earning a living. Some of them were prepared to breach ethical rules, like the greedy apothecary who sold Romeo the poison which led to Juliet's death and his. In an attempt to clarify his factual reasoning, the judge added in a footnote: "To follow the lines of Shakespeare we could say that at the core of this case is the extent to which guaranteeing the quality of pharmaceutical services requires making some pharmacists rich".

The underlying message of the Spanish judge (who was trained in a civil law country) seems to be that the Spanish government was wrong to presume that a limited number of practising pharmacists guarantees pharmaceutical services of better quality.

\subsubsection{Attempt to clarify the judge's legal reasoning} which he attributed to a conspiracy of the legal profession (1827: 296). Indeed some judgements are difficult to understand without help. After setting out the facts of a case, judges usually go through the legal issues on which the parties rely. References to or quotations from Shakespeare's plays may aim to clarify a legal concept, but this result is not always achieved. Consideration is given here to four cases. similar to those used in a newspaper article constituted "reproduction" under article 2 of Directive 2001/29/EC. In paragraph 58 of his opinion, Advocate General Trstenjak held: "One cannot [...] define reproduction in part in a strictly quantitative manner or on the basis of a de minimis criterion, which would determine in a precise manner [...] how many words of a given work suffice to constitute reproduction in part". In a footnote, he added:

For poems and well-known quotations, a few words suffice to constitute reproduction. Thus for example the quotation 'Et tu, Brute?' contains only three words, but there can be no doubt that this is a reproduction in part of the words of the play 'Julius Caesar' by William Shakespeare.

31 The relevance of the Julius Caesar quotation is undeniable. It clarifies the Slovenian judge's reasoning regarding the reality of a breach of copyright. Prior knowledge of the play is unnecessary to understand it. Interestingly, the judge attributes to Shakespeare the words "Et tu, Brute?". In fact these three words are believed to be the last ones which the real Julius Caesar told Marcus Brutus (whom he believed to be his friend) just before he was assassinated. They have become common parlance to describe someone's unexpected betrayal of someone else.

In Achour v. France, Judge Boštjan Zupančič gave his opinion on whether the French courts were in breach of article 7 of the European Convention when they applied article 132-9 of the French Criminal Code to Mr. Achour, who was found guilty by the French courts of repeat drug trafficking. According to this article: "No one shall be held guilty of any criminal offence on account of any act or omission which did not constitute a 
criminal offence under national or international law at the time when it was committed". The judge held:

The act [...] must be an authentic manifestation of the actor's being, of his or her mental status, of his or her personality. Premeditation [...] invites a higher level of criminal liability [...] than an act committed in the heat of passion. Mental illness (insanity) on the other hand severs the connection between the personality (being, status) and the act. This is why Shakespeare makes Hamlet say:

"If Hamlet in his madnesse did amisse,

That was not Hamlet, but his madnes did it, and all the wrong I e're did to Leartes,

I here proclaim was madnes." [Hamlet (Quarto 1) V.2]

With this quotation, the judge reminds his readers that in France, pleading insanity is the only way to avoid criminal liability for an undisputed offence. Mr. Achour cannot avoid criminal liability unless he proves he was insane.

In Regione Siciliana v. Commission (Regional policy), the Region of Sicily challenged a court order dismissing its action for annulment brought against a European Commission decision. The Commission had withdrawn financial assistance previously granted by the European Regional Development Fund. The disputed court order held that the European Commission decision was not of direct concern to the Region of Sicily for the purposes of the fourth paragraph of article $230 \mathrm{EC}$, thus meaning that the Region of Sicily had no standing in court.

In paragraph 52 of his opinion, the late Advocate General Ruiz-Jarabo Colomer raised the issue of the occasional "lack of will" of national member states' legislature to comply with the European Commission's wishes. The judge held: “As Shakespeare wrote, 'there is no power in Venice can alter a decree established: twill be recorded for a precedent, and many an error by the same example will rush into the state"'. In a footnote he added:

W. Shakespeare, The Merchant of Venice: reply by Portia, passing herself off as a young lawyer from Rome, to Shylock's demand for enforcement of the penalty provided for in a loan on the ground that the three thousand ducats owed have not been repaid by the due date; the penalty is that the borrower should surrender a pound of flesh cut from his chest. Shylock refuses to show any form of mercy. Bassanio begs Shylock to overlook the literal meaning of the terms of the bond so as to avoid the cruelty involved in its enforcement.

The case raises administrative and financial issues and so does the above quotation, which is relevant. The judge uses Shakespeare to explain the difference between the "literal" construction of a legal provision and its possible wider interpretation. However, the language of the quotation is so complex that the judge felt the need to explain the background of The Merchant of Venice in a footnote. Without this explanation, the quotation might have made the legal issues even more complex to understand.

In Lindon, Otchakovsky-Laurens \& July v. France, the applicants (a writer, a publisher and a journalist from a French newspaper) complained about the violation of their right to freedom of expression under article 10 and article 6-1 of the European Convention. This followed their conviction by the French courts for defamation, following allegations in a book entitled Jean-Marie Le Pen on Trial. Judge Loukis Loucaides concurred with the European Court's holding that there had been no violation of the freedom of expression. He also stressed that the European Convention, which "expressly protects rights of lesser importance, such as the right to respect for 
one's correspondence", also directly protects more important rights like "a person's dignity". In a footnote he added:

the following well-known words of Shakespeare come to mind: "Good name in man and woman, dear my lord, is the immediate jewel of their souls [...] who steals my purse, steals trash [...]; but he that filches from me my good name [...] makes me poor indeed". (Othello, Act III, scene 3)

The Cypriot judge compares the dignity of Othello the Moor to that of French rightwing politician Jean-Marie Le Pen. Both need protection against defamation. The quotation is relevant. However, many people may not agree that this quotation is "wellknown". Interestingly, if most of Shakespeare's Othello takes place in Venice, Othello and some other characters travel to Cyprus, the judge's native country.

\subsubsection{Literary embellishment}

Three examples are given below in which the judge seems keen on adding mere flourish to a court decision when referring to or quoting Shakespeare: (1) Ahokainen and Leppik is an ECJ case relating to the free movement of goods within Europe, (2) Ireland v. United Kingdom and (3) Tyrer v. United Kingdom are two ECHR cases dealing with the interviewing techniques used against alleged terrorists and the corporal punishment of juveniles.

In Ahokainen and Leppik, the court had to resolve a public health matter requiring the interpretation of two statutory provisions regarding the export or import of spirits within Europe. The question put to the court was whether a prior licence was required by the European member state for the import of spirits.

The opinion of Advocate General Poiares Maduro starts with the following words: "Good wine is a good familiar creature if it be well used. It is astonishing, however, 'that men should put an enemy in their mouths to steal away their brain', when the enemy in question, unlike good wine, is as ferocious as virtually pure ethyl alcohol". In a footnote the judge attributed those words to Othello. The quotation here neither clarifies a fact nor a legal provision. It is even misleading. When quoting Shakespeare, the judge appears concerned about the effects of strong alcoholic drinks. However, in his actual decision, he interprets article $28 \mathrm{EC}$ as prohibiting national legislators from requiring a licence for the import of strong spirits within the European Union.

In the 1978 case, Ireland v. United Kingdom, the Irish government disputed the legality of the interrogation "techniques" used in the 1970s against terrorist suspects. The question put to the European court was whether they constituted "inhuman and degrading treatment" or "torture" under article 3 of the convention. The court held that some of these interrogation methods were "inhuman treatments". In his opinion Judge Fitzmaurice held: "If instead of dealing in subjectivities, some objective criteria of what constitutes the inhuman are sought, the dictionaries furnish a very positive reply". In a footnote he explained that the last few words (i.e., "a very positive reply") were used by Shakespeare "Romeo and Juliet, Act II, Scene 2, line 43". However, they are bland words which could have been used by people other than Shakespeare and the fact that Shakespeare used them does not add any factual or legal value to the judge's reasoning.

In Tyrer v. United Kingdom, another case in which the same Judge Fitzmaurice gave his opinion, the judge openly talked about his (British) academic background. The case 
revolved around the legality of "birching" juveniles in the Isle of Man in the early 1970s. In his dissenting opinion, the judge explained that when he was at school, corporal punishment was "preferable to probable alternative punishments such as being kept in on a fine summer's evening to copy out 500 lines or learn several pages of Shakespeare or Virgil by heart". This very personal comment helps in understanding why Judge Fitzmaurice is not against the principle of corporal punishment. However it fails to support the factual background or the legal issues raised in this matter.

\section{Literature and law at a crossroads}

Before drawing conclusions from the previous cases, a brief summary of the ongoing changes in the relationship between literature -in general- and law must be made. Combining law and literature is a fairly recent phenomenon in common law countries, where literature can be integrated into legal education. Referring to the USA's Supreme Court justices and where they find inspiration to draft their opinions, Adam Liptak explains:

Justice Ruth Bader Ginsburg [...] said her style owed something to Vladimir Nabokov, the author of "Lolita". Justice Stephen G. Breyer [...] said he looked abroad for literary inspiration, mentioning Montesquieu, Wittgenstein, Stendhal and Proust [...]. Justice Kennedy [...] had barely started talking when he began quoting from Hamlet, and he went on to discuss Dickens, Trollope, Faulkner and Solzhenitsyn. (2011)

Judges in the United Kingdom (and Ireland) have often referred to or quoted Dickens, ${ }^{11}$ Stevenson ${ }^{12}$ or Shakespeare ${ }^{13}$ in their court decisions, amongst many authors.

This interdisciplinary movement now seems to be taking a new turn with the use of literature by European court judges trained in civil law countries. All law students in Europe will eventually be confronted to European law, even when their main focus of study is civil law. They need to understand how literature can be used appropriately in a legal context.

\subsection{Development of a "Literature in Law" movement}

Former United States Supreme Court Justice Benjamin Nathan Cardozo was amongst the first people who, in the 1930s, brought the words law and literature together. For Cardozo, judges should be inspired by the ways in which ideas are expressed by a novelist or a playwright: "in matters of literary style the sovereign virtue for the judge is clearness" (1931: 7).

The birth of the "Law and Literature" movement (which goes beyond literary stylistic issues) is usually attributed to American Law professor James Boyd White. From 1973, ${ }^{14}$ he stressed that law was intertwined with literature and other sciences: "The lawyer and the literary critic, as readers of texts, face difficulties and enjoy opportunities that are far more alike than may seem at first to be the case" (1981-1982: 415). From then on, two subdivisions to this popular movement in common law countries emerged: "Law in Literature" and "Law as Literature".

"Law in Literature" focuses on how trials (for instance) are described in literature. A perfect example is Charles Dickens' Bleak House. The "Law as Literature" movement aims to improve legal understanding by using the techniques of literary critics to 
examine a legal text. It is a development and an improvement of Cardozo's original movement. Senior United States judge Richard Posner said: "Opinions and briefs are like stories; they have a narrative structure. A literary sensibility may enable judges to write better opinions and lawyers to present their cases more effectively" (2009:5).

In common law countries, the use of literature in legal briefs, opinions or decisions is not recent and is fast developing. Shakespeare was first quoted by the United States Supreme Court in 1893 in Magone v. Heller (Skilton 1991: 4). Lindsley Armstrong Smith indicates that Shakespeare has been "quoted by American courts more often than any other literary figure or dramatist" (2008: 1). More precisely all of Shakespeare's 37 plays have been quoted in more than 800 judicial opinions by American courts (Peterson 1999: 789).

51 Common law being born in England, United Kingdom and Irish judges have of course quoted Shakespeare on a regular basis. In Sharp v. Anor \& ors, ${ }^{15}$ Lord Justice May criticised the lower judge for "wrongly look[ing] for a 'King Lear' moment which would explain why Mr Adam disinherited his daughters". In Hudson v. Leigh, ${ }^{16}$ Justice Bodey had to decide whether a romantic ceremony which had taken place in South Africa constituted a marriage or not. He ruled that "the 'marriage within a play' example (such as in Romeo and Juliet) [...] is a 'non-marriage". In 2007, Shakespeare was even quoted by the then Master of the Rolls regarding the replacement of the former Law Lords by the United Kingdom Supreme Court: "I leave you with one thought, borrowed as I am sure you will all recognise from Shakespeare: '... that which we call a rose by any other name would smell as sweet.' What is true for roses is, I am sure, just as true for Law Lords". ${ }^{17}$ When the United Kingdom Supreme Court replaced the appellate committee of the House of Lords, this gave rise to other -and somewhat surprisingliterary references. Just before the Supreme Court Justices took over from them in 2008, the former Law Lords handed down their decision in Majorstake v. Curtis. ${ }^{18}$ Whilst interpreting section 47(2)(b) of the Leasehold Reform, Housing and Urban Development Act 1993, Lord Scott held:

Harry Potter, we are told, received letters addressed to him at "The Cupboard under the Stairs, 4 Privet Drive, Little Winging". "The Cupboard under the Stairs" might have constituted "premises" for the purpose of letters from Hogwarts but for the purposes of construction of the 1993 Act a normal use of the English language must be assumed. (par. 16)

The first ever reference to the famous series of children's fantasy literature by J.K. Rowling is evidence of the judges' willingness to try to make themselves more accessible to people.

From James Boyd White's original "Law and Literature" movement (from which the "Law in Literature" and "Law as Literature" branches emerged), there now seems to be a third branch to White's movement which can be called "Literature in Law". This phenomenon which developed in the United States before pervading the United Kingdom now spreads into the European court system. However a number of (not always positive) conclusions can be drawn from the use of Shakespearean literature in the above European cases.

First, if judges from both European courts seem keen on imitating their common law colleagues, their civil law background (save for judges in the United Kingdom and Ireland) makes their task more complex when they use literature. Thus, it is difficult for them to apply Cardozo's concept of "clearness" to their decisions. 

becoming part of the European judicial process. However, Richard Posner rightly pointed out that "the biggest danger in any disciplinary field is amateurism [...]" (1988: 363). The judges trained in non-common law countries, like France, are potentially at a disadvantage when it comes to making an appropriate use of literature in their opinions. interdisciplinary approaches to the study of law (drawing on [...] history, philosophy, [...] literature)" (2002). Because European law prevails over national law, all law students around Europe come across ECJ or ECHR decisions, at least during their studies. In an ideal world, students should be trained to have a good understanding and knowledge of literature as part of their law studies. The need for interdisciplinarity is obvious but it is difficult to see how that need could be fulfilled.

61

egarding law and literature interdisciplinarity in the United States, Allen Mendenhal said: "many legal terms used by Shakespeare are quickly recognizable even to first year American law students [...]" (2011: 7-8). In 2004, Desmond Manderson decided to set up "the Shakespeare Moot Project" at Canada's McGill University. The project was an interdisciplinary experience bringing together an equal number of English literature and law students. The purpose of the project was to set up mixed teams of students, to give them a fictional problem of law and ask them to resolve it by answering the following question: "if Shakespeare were the law, what arguments on the basis of the 
plays would they make?" (2004: 286). A successful exchange between the students followed which led the author to make the following comments:

Their enthusiasm and their love of learning proved infectious, and they were soon studying a wide range of theoretical material on the nature of law and legal interpretation, including Cover, Hart, Fuller, Dworkin, Goodrich, and Derrida, as well as the abundant secondary literature in Shakespearean studies. Furthermore, the students proved model interdisciplinary scholars: they taught each other [...]. (2004: 286)

Within Europe, the United Kingdom and Ireland have a common law system. They share with Shakespeare the same language. Taking the example of French universities, most law students will have heard of Romeo and Juliet, Othello or the Merchant of Venice. However, and unless they get the appropriate teaching, they will not know how to make good use of Shakespeare (or indeed any other Anglophone or non-Anglophone author) in connection with their legal work. The idea here is obviously not for legal English teachers to teach their students literature -whether Shakespeare or any other author- but when and how to use it, in the interest of European justice.

With the increasing role played by the European Union and the European courts, all future civil law practitioners must understand European case law. Most if not all of them will one day need to explain a European court decision to their clients, draft a pleading and submit it to a European court or (more rarely) draft a European court decision. If current European court judges sometimes make a clumsy use of literature in their opinions, law students across Europe, and in particular those from civil law countries, for whom the "Literature in Law" movement is a new phenomenon, should be taught how to use, or interpret the use of literature as a judicial support. This is an investment for the future.

This is a daunting but interesting task for legal English specialists. Shakespeare's universality, the timelessness of his works and his popularity make him a perfect starting point for those teaching legal English and students alike. As explained by Robert Peterson: "Apart from embellishing legal writing with lofty language, Shakespeare sometimes drives decisions in substantive ways, or at a minimum supports conclusions towards which the court may tilt $-\mathrm{a}$ form of literary precedent brightening strings of dreary case citations" (1999: 795).

\section{Conclusion}

According to Richard Posner (2009: xi), "the skilful judge, like the skilful detective story teller, keeps the reader reading by deferring announcement of the resolution to the end of the opinion." A common law decision should unravel like the plot of a novel. This is also true of ECJ and ECHR decisions. The examples given above show that, over the last few years, some European judges have developed an interest in using literature in their legal opinions, more or less appropriately, to clarify a factual or legal issue or merely add a personal comment.

The use of literature to explain, support or embellish a legal opinion has now spread from common law countries, where the phenomenon is well established, to the European courts. European court judges have already shown their willingness to adapt to a developing trend, albeit sometimes clumsily. Shakespeare seems to be one of the judges' favourite authors. This is no doubt due to his universality or, to use words 
usually attributed to Ben Jonson, to the fact that Shakespeare "was not of an age, but for all time!" (Isherwood 2012). However, the hybrid common and civil law system of the ECJ and the ECHR and the civil law training which most European court judges initially receive in their countries may be two potential hurdles to the effective use of literary references or quotations in judicial decisions.

The demand for interdisciplinary legal and literary teaching in civil law countries such as France is likely to rise in view of the developing "Literature in Law" movement, of the increasing caseload of the ECJ and the ECHR and of the need for European civil lawyers to be familiar with European courts precedents. Of course, legal English teachers cannot be expected to include the teaching of literature into their existing tasks. Nevertheless, they may wish to become prepared to tell their students how to use literature in the best interest of justice.

Last but not least, the use of literature in legal decisions should be for the ECJ and ECHR a way to "ensure that a passage materially advances, illustrates, or punctuates [their] argument" (Peterson 1999: 794). Literature in law can be a great judicial tool to clarify the factual or legal meaning of a decision.

\section{BIBLIOGRAPHY}

Armstrong Smith, Lindsley. 2008. "Law imitating art: American judicial opinions performing The Merchant of Venice". Communication Law Review 8/2, 1-24.

Bentham, Jeremy. 1827. Rationale of Judicial Evidence: Specially Applied to English Practice. Vol. 4. London: Hunt \& Clarke.

Bravin, Jess. 2008. "Justice Stevens renders an opinion on who wrote Shakespeare's plays". Wall Street Journal. Retrieved on 30/10/2011 from <http://online.wsj.com/article/

SB123998633934729551.html>.

Cardozo, Benjamin, N. 1931. Law and Literature and Other Essays and Addresses. New York: Harcourt, Brace \& Co Inc.

Derrida, Jacques. December 1986. “Deconstruction: A trialogue in Jerusalem”. Mishkenot Sha'ananim Newsletter 7, 1-7.

Elkins, James R. 2002. What Exactly, is "Narrative Jurisprudence"? College of Law, West Virginia University. Retrieved on 1/3/2012 from <http://myweb.wvnet.edu/ jelkins/narrjuris02/ intro.html>.

Ginsburg, Ruth Bader. 2010. “The role of dissenting opinions”. Minnesota Law Review 95, 1-8.

Isherwood, Charles. 2012. "Ben Jonson: In and Out of Shakespeare's Shadow". New York Times 19/1/2012. Retrieved on 5/1/2012 from <http://www.nytimes.com/2012/1/22/books/review/ ben-jonson-a-life-by-ian-donaldson-book-review.html?pagewanted=all\&_r=0>.

Letsas, George. 2011. “Judge Rozakis's separate opinions and the Strasbourg dilemma". 25/6/2011. Retrieved 26/12/2011 from <http://ssrn.com/abstract=1872384>. 
Liptak, Adam. 2011. "Keep the briefs brief, literary Justices advise". New York Times 20/5/2011. Retrieved on 17/1/2012 from <http://www.nytimes.com/2011/05/21/us/politics/21court.html>.

Manderson, Desmond. 2004. "In the tout court of Shakespeare: Interdisciplinary pedagogy in law". Journal of Legal Education 54, 283-303.

Mendenhall, Allen. 2011. "Shakespeare's place in Law-and-Literature”. Journal of Liberty and Society 3, 1-17.

Oberto, Giacomo. 2003. Recrutement et formation des magistrats en Europe: Étude comparative. Éditions du Conseil de l'Europe. February 2003. Retrieved on 13/1/2012 from <http://www.coe.int/t/dghl/ cooperation/lisbonnetwork/rapports/LivreOberto_fr.pdf>.

Peterson, Robert. 1999. “The Bard and the Bench: An opinion and brief writer's guide to Shakespeare". Santa Clara Law Review 39, 789-807.

Posner, Richard A. 1988. Law and Literature: A Misunderstood Relation. Cambridge: Harvard University Press.

Posner, Richard A. 2009 [1973]. Law and Literature. Cambridge: Harvard University Press.

Rushton, William Lowes. 1918. Shakespeare a Lawyer. Liverpool: Webb \& Hunt.

Senter, John H. 1903. Was Shakespeare a Lawyer? Montpelier, VT: Argus and Patriot Press.

Skilton, Robert H. Spring 1991. "Shakespeare and the Supreme Court". The Gargoyle 21/4, 4-9.

Madison: University of Wisconsin Law School Press.

Tetley, William. 1999. "Mixed jurisdictions: common law vs. civil law (codified and uncodified)". Uniform Law Review (N.S.) 3, 591-619. Retrieved on 5/2/2012 from <http://www.mcgill.ca/ maritimelaw/comparative/mixedjur-1/>.

"The bard and the Bench". Law Society Gazette. 3/6/1987. Retrieved on 4/1/2013 from <http:// www.lawgazette.co.uk/news/the-bard-and-bench>.

Villiers Gemette, Elizabeth. 1989. "Law and literature: An unnecessarily suspect class in the liberal arts component of the law school curriculum". Valparaiso University Law Review 23/3, 267-340. Retrieved on 24/2/2012 from <http://scholar.valpo.edu/cgi/viewcontent.cgi? article $=2049 \&$ context $=$ vulr $>$.

Welles, Orson. 1939. The Mercury Shakespeare: Macbeth. New York: Harper \& Brothers.

White, James B. 1981-1982. “Law as language: reading law and reading literature”. Texas Law Review 60, 415-429.

\section{Webliography}

British and Irish Legal Information Institute. <www.bailii.org>. European Union caselaw, British and Irish caselaw and legislation, Law Commission reports and other law-related material can be found on BAILII. Accessed on 30/10/2011, 5/11/2011 and on 20/9/2012.

Civitas EU facts <http://www.civitas.org.uk/eufacts/FSINST/IN5.htm>. This website has various facts and figures about the Court of Justice of the European Union. Last updated on 21/7/2011.

Durham University. <http://www.dur.ac.uk/resources/deli/annuallecture/ Sharpston_bio_2006.pdf>. Presents the CV of Advocate General Elenaor Sharpston Q.C. Last updated on 16/10/2006. 
École Nationale de la Magistrature. <http://www.enm.justice.fr/_uses/lib/5762/

Programme_pedagogique_2011.pdf>. Presents the 2011 programme pédagogique for aspiring French magistrats. Accessed on 8/1/2012.

Kent University. <http://www.kent.ac.uk/law/undergraduate/english.html>. Describes the fouryear degree programme taught at Kent Law School and called law and English Literature. Last updated on $11 / 10 / 2012$.

Legifrance. <www.legifrance.gouv.fr>. Official French website on which French codes, caselaw from the judicial and administrative branches and statutes (as well as decrees etc.) can be found, sometimes translated in various languages. We looked up the word "Shakespeare" in the precedents of the Cour de Cassation, and found four cases which were all irrelevant to Shakespeare's works, i.e., cass. com. 3/3/2009 No. 07-20.779, cass. civ. 3 1/12/1993 No. 91-22.048, cass. civ. 1 4/4/1984 No. 83-10.635, cass. civ. 1 26/11/1980 79-14.547. Similar research carried out on the same day into the Conseil d'État's caselaw revealed no occurrences of the word Shakespeare. Accessed on 22/2/2012.

Ordre des Avocats de Paris. <http://www.avocatparis.org/efb-ecole-de-formation-au-barreau/ contenu-de-la-formation.html >. Sets out the various modules taught at the École de Formation du Barreau of Paris from the $1^{\text {st }}$ January 2012. Accessed on 4/1/2012.

\section{APPENDIXES}

\section{Appendix 1}

Relevant results obtained by entering "Shakespeare" in the "Europe" database of BAILII

\begin{tabular}{|c|c|c|c|}
\hline Names of the parties & $\begin{array}{l}\text { European court having } \\
\text { jurisdiction \& play } \\
\text { referred to or quoted }\end{array}$ & $\begin{array}{l}\text { Case } \\
\text { reference No. }\end{array}$ & $\begin{array}{l}\text { Relevant part of opinion/ } \\
\text { judgment }\end{array}$ \\
\hline $\begin{array}{l}\text { Blanco Perez \& Chao } \\
\text { Gomez (Freedom of } \\
\text { establishment) }\end{array}$ & $\begin{array}{l}\text { ECJ } \\
\text { Romeo and Juliet }\end{array}$ & $\begin{array}{l}{[2009] \quad \text { EUECJ }} \\
\text { C-570/07_O }\end{array}$ & $\begin{array}{l}\text { Paragraphs } 1 \text { and } 2 \text { (and } \\
\text { footnote) of opinion of } \\
\text { Advocate General Poiares } \\
\text { Maduro }\end{array}$ \\
\hline $\begin{array}{lll}\text { Tyrer } & \text { v. } & \text { United } \\
\text { Kingdom } & & \end{array}$ & $\begin{array}{l}\text { ECHR } \\
\text { None }\end{array}$ & $\begin{array}{l}5856 / 72[1978] \\
\text { ECHR } 2\end{array}$ & $\begin{array}{l}\text { Paragraph } 12 \text { of Judge Sir } \\
\text { Gerald Fitzmaurice's opinion }\end{array}$ \\
\hline Achour v. France & $\begin{array}{l}\text { ECHR } \\
\text { Hamlet }\end{array}$ & $\begin{array}{l}67335 / 01 \\
{[2006] \quad \text { ECHR }} \\
268\end{array}$ & Boštjan Zupančič's opinion \\
\hline $\begin{array}{l}\text { Lindon, Otchakovsky- } \\
\text { Laurens and July v. } \\
\text { France }\end{array}$ & $\begin{array}{l}\text { ECHR } \\
\text { Othello }\end{array}$ & $\begin{array}{l}21279 / 02 \\
{[2007] \quad \text { ECHR }} \\
836\end{array}$ & $\begin{array}{l}\text { Footnote } 1 \text { of Judge } \\
\text { Loucaides' opinion }\end{array}$ \\
\hline
\end{tabular}




\begin{tabular}{|l|l|l|l|}
\hline $\begin{array}{l}\text { Regione Siciliana v. } \\
\text { Commission (Regional } \\
\text { policy) }\end{array}$ & ECJ & $\begin{array}{l}{[2006] \quad \text { EUECJ }} \\
\text { The Merchant of Venice }\end{array}$ & $\begin{array}{l}\text { Paragraph 52 (and footnote) } \\
\text { of Advocate Ruiz-Jarabo } \\
\text { Colomer's opinion }\end{array}$ \\
\hline $\begin{array}{l}\text { Ahokainen and Leppik } \\
\text { Free movement of } \\
\text { goods) }\end{array}$ & ECJ & $\begin{array}{l}\text { Othello } \\
\text { C-434/04 EUECJ }\end{array}$ & $\begin{array}{l}\text { Footnote 2 of Advocate } \\
\text { General Poiares Maduro's } \\
\text { opinion }\end{array}$ \\
\hline $\begin{array}{l}\text { Infopaq International } \\
\text { (Intellectual property) }\end{array}$ & ECJ & $\begin{array}{l}\text { Julius Caesar } \\
\text { C-5/00_O EUECJ }\end{array}$ & $\begin{array}{l}\text { Paragraph 58 (and footnote } \\
22) \text { of Advocate General } \\
\text { Trstenjak's opinion }\end{array}$ \\
\hline
\end{tabular}

\section{Appendix 2}

Relevant results obtained by entering the names of Shakespeare's plays in the "Europe" database of BAILII

\begin{tabular}{|c|c|c|c|c|}
\hline $\begin{array}{l}\text { Name of } \\
\text { play }\end{array}$ & Names of parties & $\begin{array}{l}\text { Court having } \\
\text { jurisdiction }\end{array}$ & $\begin{array}{l}\text { Case } \\
\text { reference No. }\end{array}$ & $\begin{array}{l}\text { Relevant part of opinion/ } \\
\text { judgment }\end{array}$ \\
\hline $\begin{array}{l}\text { The } \\
\text { Merchant of } \\
\text { Venice }\end{array}$ & $\begin{array}{l}\text { Regione Siciliana v. } \\
\text { Commission } \\
\text { (Regional policy) }\end{array}$ & ECJ & $\begin{array}{l}{[2006] \text { EUECJ }} \\
\text { C-417/04 }\end{array}$ & See above \\
\hline $\begin{array}{l}\text { Romeo and } \\
\text { Juliet }\end{array}$ & $\begin{array}{l}\text { Blanco Perez \& Chao } \\
\text { Gomez }\end{array}$ & ECJ & $\begin{array}{l}\text { [2009] EUECJ } \\
\text { C-570/07_O }\end{array}$ & See above \\
\hline $\begin{array}{l}\text { Romeo and } \\
\text { Juliet }\end{array}$ & $\begin{array}{l}\text { Ireland v. United } \\
\text { Kingdom }\end{array}$ & ECHR & $\begin{array}{l}5310 / 71[1978] \\
\text { ECHR } 1\end{array}$ & 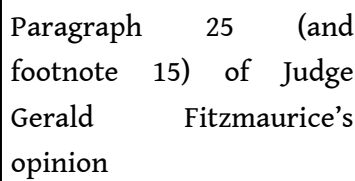 \\
\hline Julius Caesar & $\begin{array}{l}\text { Infopaq International } \\
\text { (Intellectual } \\
\text { property) }\end{array}$ & ECJ & $\begin{array}{l}{[2009] \text { EUECJ }} \\
\text { C-5/08_O }\end{array}$ & See above \\
\hline Macbeth & $\begin{array}{lr}\text { Mucksch v. } & \text { Franz } \\
\text { Mucksch OHG } & \end{array}$ & ECJ & $\begin{array}{l}{[2011] \text { EUECJ }} \\
C-53 / 10\end{array}$ & $\begin{array}{l}\text { Paragraph } 46 \quad \text { (and } \\
\text { footnote 20) } \\
\text { of Advocate } \\
\text { General } \\
\text { opinion }\end{array}$ \\
\hline Hamlet & Achour v. France & ECHR & $\begin{array}{l}67335 / 01 \\
{[2006] \quad \text { ECHR }} \\
268\end{array}$ & See above \\
\hline Othello & $\begin{array}{l}\text { Ahokainen and } \\
\text { Leppik } \quad \text { (Free } \\
\text { movement of goods) }\end{array}$ & ECJ & $\begin{array}{l}{[2006] \text { EUECJ }} \\
C-434 / 04\end{array}$ & See above \\
\hline
\end{tabular}




\begin{tabular}{|l|l|l|l|l|}
\hline \multirow{3}{*}{ Othello } & $\begin{array}{l}\text { Lindon, Otchakovsky- } \\
\text { Laurens and July v. } \\
\text { France }\end{array}$ & ECHR & $\begin{array}{l}21279 / 02 \\
{[2007] \quad \text { ECHR }} \\
836\end{array}$ & See above \\
\hline
\end{tabular}

\section{NOTES}

1. From Henry the Sixth, Part 2 Act 4 Scene 2.

2. Retrieved on 13/1/2012 from <http://europa.eu/about-eu/institutions-bodies/court-justice/ index_en.htm>.

3. See the opinion of Judge Pinto de Albuquerque in [2012] ECHR 514.

4. See paragraph 3 of Advocate General Damaso Ruiz-Jarabo Colomer's opinion [2008] EUECJ C-506/06.

5. See paragraph 6 of Judge Mifsud Bonnici's opinion in [1994] ECHR 39.

6. See Judge Bonello's opinion in [2011] ECHR 2412.

7. Numerous books have been published on the most famous Shakespearean legal quotes or Shakespeare's relationship with the law.

8. We refer here to the Oxfordian theory by which some scholars and historians argue that Edward de Vere, Earl of Oxford, wrote the plays attributed to Shakespeare. This was the conclusion reached in 2008 by federal Supreme Court Justice Stevens, himself an Oxfordian, when he rendered a mock legal decision in which he pointed out that there were no books in Shakespeare's former Stratford house: "I think the evidence that he was not the author is beyond a reasonable doubt" (Bravin 2008). The judge used the standard of evidence required in criminal trials.

9. Jackson International v. OHMI - Royal Shakespeare [2012] EUECJ T-60/10.

10. Gisayev v. Russia - 14811/04 [2011] ECHR 76.

11. Booth v. Booth \& Ors [2010] EWCA Civ 27 - 05/2/2010 - paragraph 71.

12. Regina v. Randall [2003] UKHL 69 - 18/12/2003 - paragraph 10.

13. See R v. A (No 2) [2001] EWCA Crim 4 case No: 200007157/S2 - 15/1/2001 - paragraph 23.

14. When The Legal Imagination was first published.

15. [2006] EWCA Civ 449 No. A3/2005/1846 - 28/04/2006 - paragraph 80.

16. See [2009] EWHC 1306 (Fam) No. FD08D00383 - 05/06/2009 - paragraph 69.

17. See Sir Anthony Clarke MR's speech given at Hertfordshire University on $1 / 11 / 2007$ retrieved on 4/1/2013 from <http://www.judiciary.gov.uk/Resources/JCO/Documents/Speeches/ mr_hertsuniv_011107.pdf>. Interestingly the Master of the Rolls implies that his audience (academics and lawyers) should all be conversant with Romeo and Juliet.

18. [2008] UKHL 10.

19. Murray v. The United Kingdom 14310/88 [1994] ECHR 39, Allen v. The United Kingdom 18837/06 [2010] ECHR 420 and Umbach v. Commission [2010] EUECJ T-474/08.

20. Mayr v. Backerei und Konditorei Gerhard Flockner OHG [2008] EUECJ C-506/06 and Beecham Group \& Ors (Customs union) [2008] EUECJ C-132/07_0.

21. Neukirchinger (Freedom to provide services) French Text [2010] EUECJ C-382/08 (7/9/2010).

22. Telecom Italia (Freedom to provide services) French Text [2007] EUECJ C-296/06

(25/10/2007).

23. Tadao Maruko (Social policy) (French Text) [2007] EUECJ C-267/06 (6/9/2007). 


\section{ABSTRACTS}

Under the influence of common law countries, European Court of Justice and European Court of Human Rights judges now also use literature in their decisions. Within the "Law and Literature" movement, a "Literature in Law" sub-movement has emerged. For example, European judges who may have been trained in civil law countries refer to or quote Shakespeare's plays in their opinions or judgements. The incorporation of literature into law goes towards an increasing interdisciplinarity, which should be taken into account by those teaching law students and, in particular, legal English specialists. The part played by literature in law is considered through the study of a number of European court decisions written in English. The purpose is to determine why, how, and to what extent the role of those teaching legal English is likely to evolve to address the changing needs of students.

Sous l'influence des pays de common law, les juges de la Cour de justice de l'Union européenne et de la Cour européenne des droits de l'homme utilisent désormais aussi la littérature dans leurs décisions. Au sein du mouvement "Droit et Littérature", un sous-mouvement "Littérature dans le Droit" émerge. Ainsi, les juges européens, qui ont pu être formés dans des pays de droit civil, citent ou se réfèrent aux pièces de Shakespeare dans leurs opinions ou jugements. L'immixtion de la littérature dans le droit va dans le sens d'une interdisciplinarité accrue. Elle influe sur le rôle des enseignants formant les juristes et notamment, des spécialistes d'anglais juridique. Le rôle joué par la littérature dans le droit européen est examiné au travers de l'étude de quelques décisions des juridictions européennes rédigées en anglais. L'objectif est de déterminer pourquoi, comment et dans quelles limites la mission des enseignants d'anglais juridique est susceptible d'évoluer pour répondre aux nouveaux besoins des apprenants.

\section{INDEX}

Mots-clés: anglais juridique, Cour de justice de l'Union européenne, Cour européenne des droits de l'homme, droit et littérature, littérature dans le droit

Keywords: European Court of Human Rights, European Court of Justice, law and literature, legal English, literature in law

\section{AUTHOR}

\section{GÉRALDINE GADBIN-GEORGE}

Géraldine Gadbin-George is a Senior Lecturer at Université Panthéon-Assas, where she teaches legal English. Prior to entering higher education, she served as a lawyer in France and in England. Her research work deals with access to justice in England and Wales, as well as comparative law. She recently published in Revista Critica Penal y Poder (Barcelona) and Comparative Law Review (North America). geraldine.george@gmail.com 